\title{
Pathogenesis of Helicobacter pylori infection
}

\author{
PHILIP M SHERMAN, MD, FRCPC, BFanamin D (GOLI), MD)
}

P Sherman, B Gold. Pathogenesis of Helicobacter pylori infection. Can J Gastroenterol 1993; 7(5):395-405. The following aspects of Helicobacter pylori infection are summarized: virulence factors causing $H$ pylori-induced type $B$ gastritis, the role of $H$ pylori in nonulcer dyspepsia, the pathogenesis of $H$ pylori-associated peptic ulceration, and mechanisms of chronic H pylori infection which could result in gastric carcinogenesis.

Key Words: Adhesion, Gastric cancer, Helicobacter pylori, Toxin, Ulcers, Urease

\section{Pathogenèse de l'infection à Helicobacter pylori}

RÉSUMÉ: Les aspects suivants de l'infection à Helicobacter pylori sont résumés ici: facteurs de virulence responsables de la gastrite de type $\mathrm{B}$ induite par $\mathrm{H}$ pylori, le rôle de $H$ pyloni dans la dyspepsie non ulcéreuse, la pathogenèse de l'ulcère peptique lié à $H$ pylori, et les mécanismes de l'infection à $H$ pylori qui pourrait évoluer vers une carcinogenèse gastrique.

$\mathrm{T}$ HE GRAM-NEGATIVE, SPIRAL. shaped organism currently referred to as Helicobacter pylori (1) is established as a human pathogen causing a histopathologically evident chronicactive gastritis (2). There is specificity to the infection because other known causes of gastritis, including gastroduodenal Crohn's disease, eosinophilic gastroenteritis and drug ingestion, are not correlated with $H$ pylori colonization of the antrum (3-5). Challenge of both human volunteers $(6,7)$ and laboratory animals (8) results in the development of chronic-active gastritis. In addition, therapy clearing the hacterial infection results in resolution of the gastritis (9). Therefore, $H$ pyloni infection and colonization of the stomach fulfils each of Koch's postulates as a cause of chronicactive gastritis in humans (10). Accumulating evidence indicates that this organism also has an etiopathogenic role in peptic ulcer disease and gastric carcinoma, even though each of Koch's postulates have not yet been fulfilled.

Division of Gastroenterology, Research Institute. The Hospital for Sick Children:

Departments of Pediatrics and Microbiology, University of Toronto. Toromto, Ontario

Correspondence: Dr Philip Sherman, Division of Gastroenterology (Room 1448). The Hospital for Sick Children, 555 University Avenue. Toronto, Ontario M5G IX8. Telephone (416) 813-6185, Fax (416) 813-6531

Several reports question whether this infection also may be a factor in the etiology of clinical symptoms in the absence of endoscopic evidence of peptic ulceration. The pathogenesis of $H \mathrm{py}$ lori-induced gastroduodenal diseases is not clearly established (11-13). Therefore, this review will highlight recent findings characterizing both the virulence properties of $H$ pylori and the host responses likely involved in the pathogenesis of disease. The pathogenesis of H pylori infection in gastritis, nonulcer dyspepsia, peptic ulcerative disease and gastric carcinoma will be considered in sequence.

\section{H PYLORI-INDUCED GASTRITIS}

Although it is now established that $H$ pylori infection is a cause of chronicactive (type B) gastritis, the precise mechanisms involved in the induction of mucosal inflammation in the antrum are not clear. A general consideration of the factors involved in the etiopathogenesis of disease caused by other bacterial enteropathogens includes ingestion of the organism from a reservoir, colonization of mucosal sites and bacterial adhesion to mucosal surfaces, followed by either toxin production or mucosal invasion (14). Therefore, following a similar outline this review will consider the potential virulence properties of $H$ pylori which 


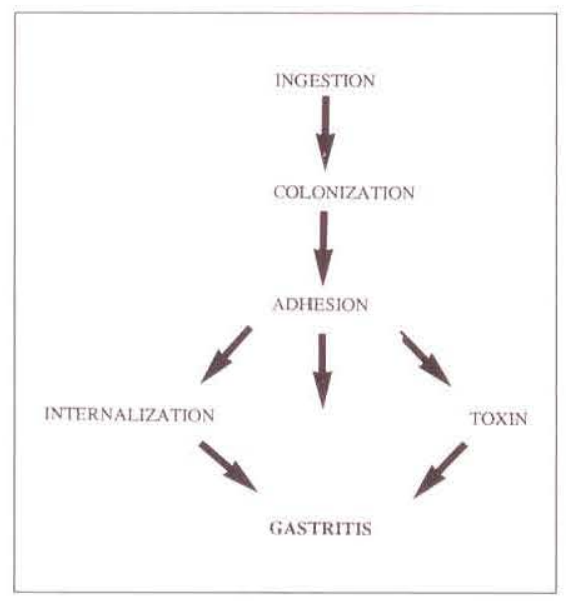

Figure 1) Model of the stages by which Helicohacter pyloricauses chromic-active (type B) gastritis

may be implicated in the induction of gastritis (Figure 1).

Ingestion: As shown in Figure 1, H pylori must first gain access to the gastrointestinal tract. The reservoir for $H$ pylori infection, however, is still not known (15). Initial studies which found that the frequency of $H$ pylori-specific antibodies was higher in serum samples obtained from abattoir workers compared with controls suggested that the organism might be acquired as a zoonotic infection (16). A more recent report implicating $H$ pylori as a zoonotic infection indicates seropositivity is also higher among rural Manitobans compared with their urban counterparts (17). However, an animal reservoir for this organism has not yet been identified. Concerns have also been raised about the validity of these seroepidemiological findings as there are common flagellar antigenic epitopes in both $\mathrm{H}$ pylori and enteric campylobacters. There is also evidence of intrafamilial clustering of $H$ pylori infection (18) suggesting that person-to-person transmission of the gastric pathogen via either a fecal-to-oral or an oral-to-oral route might occur. The organism was recently successfully cultured from stool samples by employing selective growth media (19). Reports that dental plaque might serve as a reservoir for this gastric pathogen (20) suggest that H pylori might be transmitted through excretion in saliva.

Epidemiological evidence of childhood overcrowding as a risk factor for the acquisition of $H$ pylori also suggests that there might be person-to-person transmission of the infection $(21,22)$. However, another possibility is that an environmental source of $\mathrm{H}$ pylori places individuals residing within a common setting at risk for acquisition of the infection. Additional studies are clearly required to establish the environmental reservoir of $\mathrm{H}$ pylori.

Motility: $H$ pylori is a flagellated organism characterized by rapid darting movements when visualized under phase-contrast microscopy (23). Recent experimental evidence suggests that motility conferred by the flagella is an important virulence factor for this hacterium. Eaton et al (24) tested nonmotile variants of $\mathrm{H}$ pylori in a gnotobiotic piglet model of $\mathrm{H}$ pylori-induced chronic gastritis. Only two of eight piglets infected with the nonmotile strain developed colonization of the stomach compared with nine of 10 piglets challenged with a motile $H$ pylori isolate. Although isogenic mutants were not employed, these initial findings suggest that this organism's motility properties increase its access to both the gastric epithelium and the overlying mucous layer which then serve as the local environmental niche for long term colonization of infected humans.

Colonization: During infection in vivo $H$ pylori colonizes the mucous layer overlying gastric epithelium. In vitro the organism does not survive below a $\mathrm{pH}$ of 2.5 (25). In vivo the organisms do not reside within the highly acidic lumen of the stomach, but rather in the more neutral $\mathrm{pH}$ environment formed by the mucus-bicarbonate layer immediately adjacent to the gastric epithelial surface (26).

Recent studies show that $H$ pylori adheres to isolated gastric mucus in vitro. Sodium metaperiodate-induced oxidation of sugar side-chains reduces binding of mucins to $\mathrm{H}$ pylori indicating that carbohydrate side-chains on the mucus glycoprotein are involved in mediating attachment of the organism (27). Other investigators have shown that gastric mucus is degraded by urease $(28,29)$ which is a preformed, surfaceexposed enzyme that is present on the bacterial cell surface (30). Further re- search has shown that surface hydrophobicity in the stomach is conferred by the overlying gastric mucous layer (31-33). Measurements of the contact angle, as a determinant of surface hydrophobicity, on gastric mucosal biopsies obtained from patients with $H$ pylori infection (59.) are significantly lower than on biopsies obtained from subjects without $H$ pylori infection and chronic-active gastritis $\left(70^{\circ}\right)(34)$. The contact angles return towards normal values following eradication of the $H$ pylori infection (35). Therefore, disruption of gastric mucus integrity by $H$ pylori and its products could account for these observed changes in surface hydrophobicity. The urease enzyme could reduce the surface hydrophobicity of the infected antral mucosa by degrading mucus $(28,29)$. One group reports that $\mathrm{H}$ pylori elaborates a protease that is also capable of degrading native gastric mucus glycoproteins (36). However, evidence of proteolytic activity in $H$ pylori strains has not been confirmed by other investigators (37).

The genes encoding for production of the structural subunits of the urease enzyme, as well as regulatory and accessory proteins, have been cloned and sequenced (38-40). Use of isogenic knockout strains deficient only in the production of urease (41) should now be employed in studies to determine whether the mutants are still capable of altering the composition and functional properties of gastric mucins. As detailed below, urease has also been proposed as a virulence determinant mediating both bacterial adhesion and cytopathic effects on tissue culture epithelial cells. Therefore, isogenic urease-deficient mutants should be employed to establish whether the urease enzyme is also involved in these steps in the pathogenesis of chronic-active gastritis.

Adhesion: During infection in vivo $H$ pylori also colonizes the surface of gastric epithelium, particularly in the antrum. There is electron microscopic evidence of direct adhesion between bacteria and the apical plasma membrane of the infected eukaryotic cell $(42,43)$. Initial reports suggested a predilection of $H$ pylori to intracellular 
junctions; however, subsequent studies have not confirmed this observation (44). During adhesion of $\mathrm{H}$ pylori in vivo there is loss of the apical microvillus membrane and intimate contact between the surface of the organism and the apical plasma membrane of the epithelial cell $(43,45)$. This finding has morphologic features similar to the intimate adhesion of certain types of diarrheagenic Escherichia coli to enterocytes and colonocytes during infection of both humans and domesticated animals in vivo and following incubation with cultured epithelial cells in vitro (46).

In vitro binding of $H$ pylori to a variety of epithelial cell lines has been described including adhesion of hacteria to tissue culture cell lines derived from gastric carcinoma (eg, KATO-III cells) $(47,48)$. During infection of KATO-III cells there is initial binding to intact microvilli and evidence of disruption of the microvillus membrane with adhesion of the infecting organism to the underlying plasma membrane (47). Recent work indicates that in vitro adhesion of H pylori to both KATO-III cells and differentiated epithelial cells isolated from gastric mucosal biopsies is greater than the degree of bacterial adhesion to isolated duodenal enterocytes and colonocytes (49).

During $H$ pylori infection of isolated gastric epithelial cells of lapine origin there is decreased acid production (50) and increased pepsinogen release (51) from the infected cells. H pylori lipopolysaccharide is reported as a potential bacterial mediator inducing pepsinogen release (52). Other studies have not confirmed that there are changes in either acid production or pepsinogen release during $H$ pylori infection $(53,54)$. Thus, whether these observations correlate with changes following infection in vivo remains uncertain.

Receptor for $\mathrm{H}$ pylori binding: Previous epidemiological studies identified blood group status as a risk factor for the development of both gastritis and peptic ulcer disease; individuals with blood group $\mathrm{O}$ are at highest risk for these gastroduodenal lesions (55). Since blood group status is related to the sugar composition of glycolipids in the red blood cell membrane (56), in collaboration with Dr Clifford Lingwood, we sought to determine if there was specific binding of $\mathrm{H}$ pylori to lipids extracted from erythrocytes obtained from individuals of varying blood groups. Using a solid-phase partition binding assay based upon thin layer chromatograms (TLC) to evaluate $H$ pylori binding to separated lipids, our hypothesis was not confirmed. TLC-overlay assays demonstrated bacterial adhesion to lipids extracted from erythrocytes of $\mathrm{ABO}$ blood groups (57). This study did show, however, that there is a receptor present in the lipid extract to which $H$ pylori adheres. The same receptor is present in the antrum and, to a lesser extent, in the fundus of humans (57). The receptor is also present in tissue culture cell lines to which the organism attaches. Subsequently, the membrane receptor for H pylori binding has heen characterized as a form of phosphatidylethanolamine (58). H pylori also binds to a deacylated form of phosphatidylethanolamine (59) and to the gangliosides gangliotetraosylceramide (asialo-GM-1) and gangliotriosylceramide (asialo-GM-2) $(60,61)$. Whether these membrane receptors are surface exposed and mediate binding of $H$ pylori during the infection in vivo requires further investigation.

Adhesins expressed by $H$ pylori: The bacterial product mediating adhesion of H pylori to gastric mucus and to gastric epithelial surfaces is not yet known. It is likely, however, that multiple determinants are involved in binding of the organism to surface receptors. In a superb review of bacterial adhesion by Hasty et al (62) it was concluded that "bacteria also express multiple adhesins and further, that the adhesins probably function in distinct kinetic steps". The same review indicates that there is "no need to bring attention to the concept of multiple adhesins in Gram-negative bacteria so widespread is its acceptance". It is likely that this concept also holds true when considering $H$ pylori adhesion to gastric epithelia both in vitro and in vivo. However, knockout mutations of potential adhesin genes in the organism will be required to definitely establish whether a single virulence determinant or multiple genes encode the adhesins which promote binding of $H$ pylori to mucosal surfaces.

$H$ pylori strains are known to agglutinate erythrocytes (63-65). Hemagglutination indicates that there is a receptor on the plasma membrane of red blood cells. It also demonstrates that a hemagglutinin expressed on the bacterial cell surface mediates attach. ment. However, this mannose-resistant hemagglutination may not correlate with binding of $\mathrm{H}$ pylori to gastric epithelial cells and gastric mucus. One group has reported that $H$ pvlori expresses a hemagglutinin that hinds to a specific lactose-containing receptor and that this bacterial product also might be involved in binding the organism to epithelial surfaces (66). This hemagglutinin is expressed in vivo because there is a specific humoral response in infected individuals (67). Another group has reported that some $H$ pylori strains elaborate a soluble hemagglutinin that is a potential adhesive factor (68). However, this finding has not been duplicated in other laboratories.

Phosphatidylethanolamine, to which H pylori adheres, also serves as a receptor for binding of exoenzyme S expressed hy Pseudomonas aeruginosa (69). H pylori expresses a similar protein, referred to as exo $H$, which may serve as a ligand for attachment of this organism to lipid receptors (58). There is one study which described the identification, cloning and sequencing of a gene encoding for a nonfimbrial surface-exposed fibrillar protein on the surface of bacteria which may function as an adhesin (70). Other studies suggest that the urease enzyme might modulate H pylori adhesion or serve as a bacterial ligand (71). Flagella are described as adhesins for closely related enteric campylobacters (72). Therefore, the potential role of flagella as binding proteins for Helicobacter species should be investigated further.

For other gastroenteric pathogens, surface hydrophobicity plays a role in the initial establishment of contact between the bacteria and mucosal surfaces (73). Studies evaluating the surface hydrophobicity properties of $H$ pylori have yielded varying results $(74,75)$. These differences may be accounted for by the use of different bac- 
TABLE 1

\section{Immune responses of the host to Helicobacter pylori infection}

$\begin{array}{ll}\text { B cell } & \text { Increases in IgG, IgA, IgM } \\ \text { T cell } & \text { Increases in IL-1, IL-2, IL-2 receptor } \\ \text { Macrophage } & \text { Increases in TNF- } \alpha \text {, IL-8 } \\ \text { Epithelial cells } & \text { Expression of MHC class II antigens, increases in IP3, IL-8 } \\ \text { Polymorphonuclear leukocytes } & \text { Possible effect on nitrate production }\end{array}$

Ig Immunogiobullin: IL Interleukin: IP Inositol tris-phosphate; MHC Major histocompatibility complex: TNF Tumour necrosis factor

terial strains and variable growth conditions. It is also possible that specific hydrophobic domains, which have not yet been identified, mediate initial adhesion of the organisms to gastric epithelial surfaces (75).

Toxin production by $H$ pylori: Incubation of both H pylori and cell-free culture supernatants result in cytopathic effects in a variety of eukaryotic cells grown in tissue culture (76). It was reported that these cytopathic changes could simply relate to the potent urease activity of $H$ pylori (77). Conversely, more recent studies suggest that there is a distinct cytotoxin expressed by $H$ pylori strains that induces formation of autophagocytic lysosomes (78). The cytotoxin structural subunit, with a molecular mass of $85 \mathrm{kDa}$, has been purified and sequenced (79). The toxin is expressed during infection in vivo because antibodies to the toxin develop in $H$ pylori colonized individuals $(80,81)$. In addition, one study reported that there is a greater frequency of identifying $H$ pylori isolates producing $\mathrm{cy}$ topathic effects in vitro in individuals with peptic ulcer disease compared with subjects with gastritis alone $(82)$. This provocative finding requires confirmation at other centres. Isogenic mutants deficient in toxin production are required to define more precisely the role of toxins in $H$ pylori-induced gastroduodenal diseases.

Invasion of $H$ pylori: Most histopathological studies of infected humans have not provided evidence of bacterial invasion into the cytoplasm of surface gastric epithelial cells or the underlying interstitium. However, $H$ pylori binds to extracellular matrix proteins in vitro (83) and there are isolated reports identifying the organism within the lamina propria of gastric epithelium (84). Fol- lowing $H$ pyloni infection of cultured epithelial cells, one group reports that there is an internalization of intact, viable organisms into the cytoplasm of the eukaryotic cell (85). Whether H pylori is internalized by gastric epithelial cells requires investigation. The relevance of these in vitro findings to infection in vivo also must be defined. Genes coding for this property of internalization of the organisms into susceptible epithelial cells should be identified to confirm these initial laboratory observations.

Immune responses of the host: During Hpylori infection of humans there is the development of a chronic-active gastritis $(2,3)$. In contrast, in experimental animal models there is evidence of chronic inflammation but in most models there is no evidence of an acute inflammatory response (8). This suggests that most animal models do not provide an accurate reflection of the inflammatory responses in infected humans. Further development and detailed characterization of more appropriate animal models of $\mathrm{H}$ pylori infection are, therefore, urgently required.

As shown in Table 1, during H pylori of infiltration inte the gastric epithelium of T lymphocytes, B cells, plasma cells, macrophages and polymorphonuclear leukocytes (86). There is both immunohistochemical and immunoassay evidence of increased levels of immunoglobulins $\mathrm{G}, \mathrm{M}$ and $\mathrm{A}$ production in the local gastric microenvironment (87). However, despite the vigorous humoral and $\mathrm{T}$ cell immune responses there is little evidence to suggest spontaneous clearing of the organism once colonization and adhesion to gastric mucosal surfaces have developed. infection of humans there is evidence
TABLE 2

Proinflammatory products of Helicobacter pylori

Urease
Lipopolysaccharide
Heat shock protein
Platelet-activity factor
Phospholipase $\mathrm{A}_{2}$
Phospholipase C
Catalase

The gastritis caused by $H$ pylori infection is associated with the induction of major histocompatibility complex (MHC) class II antigen expression on the surface membrane of gastric epithelial cells (88). MHC class II antigen expression also occurs in epithelial cells in other areas of the gastrointestinal tract during acute and chronic inflammation (89). This could have important etiopathological relevance since MHC class II molecules are involved in the host mucosal immune response. In addition, murine monoclonal antibodies raised against $H$ pylori cross-react with antigens exposed on the surface of mucus-producing cells in the gastric antrum of infected individuals (90). Cross-reacting antibodies are also present in the serum of $H$ pylori-infected individuals but not in uninfected controls (91).

H pylori infection also induces infil. tration of both macrophages and neutrophils into the gastric mucosa. In vitro evidence indicates that these proinflammatory cells are activated. For example, Mai et al (92) showed that chemiluminescence of both monocytes and neutrophils is increased, in a dosedependent fashion, by cell-free culture supernatants of H pylori. This chemiluminescence response is significantly reduced by coincubation of the bacterial supernatants with anti-urease antibodies (93). This suggests that the urease enzyme also acts as a proinflammatory agent. As shown in Table 2, other bacterial constituents which might initiate the proinflammatory cascade include bacterial heat-shock proteins $(94,95)$, platelet activating factor (96), phospholipase A (97), phospholipase C (98), catalase (99), and lipopolysaccharide (LPS). LPS extracted and purified 
from $H$ pylori has a structural composition that is distinct from other Gramnegative organisms $(100,101)$ and low biological activity demonstrated with a standard limulus lysate assay $(102,103)$. However, the biological effects of $H$ pylori LPS on the gastric microenvironment and on gastric epithelial cells may differ from these in vitro assay results. Young et al (52) showed, for example, that pepsinogen release from epithelial cells is activated to a greater degree by LPS derived from $H$ pyloni than LPS extracted from other Gramnegative bacteria.

The gastric inflammatory response to $H$ pylori infection results in the release of a number of cytokines and lymphokines including tumour necrosis factor-alpha, interleukin-1, interleukin-6 and interleukin-8 (104-106). This proinflammatory cascade ultimately results in the chronic-active inflammation that is characteristic of $H$ pylori-induced gastritis. A current working hypothesis proposed by Blaser (107) suggests that by inducing this cascade the organism derives nutrients from the host for continued colonization and replication. $H$ pvlori infection also induces a signal transduction response within epithelial cells. In a preliminary study we showed that inositol triphosphate levels are elevated in the cytosol of infected tissue culture epithelial cells compared with cells grown in the presence of heterologous organisms or without bacterial infection (43). The reason(s) why these inflammatory, immune and signal transduction responses do not successfully clear $H$ pylori colonization requires explanation because it could provide information critical to the development of novel strategies to either prevent or eradicate $H$ pylori infection.

\section{PATHOGENESIS OF H PYLORI- ASSOCIATED NONULCER DYSPEPSIA}

Current evidence does not support an etiopathogenic role for $\mathrm{H}$ pylori infection as a cause of clinical symptoms in the absence of active peptic ulceration (108). Most studies evaluating adults with nonulcer dyspepsia do not provide evidence of an increased rate of

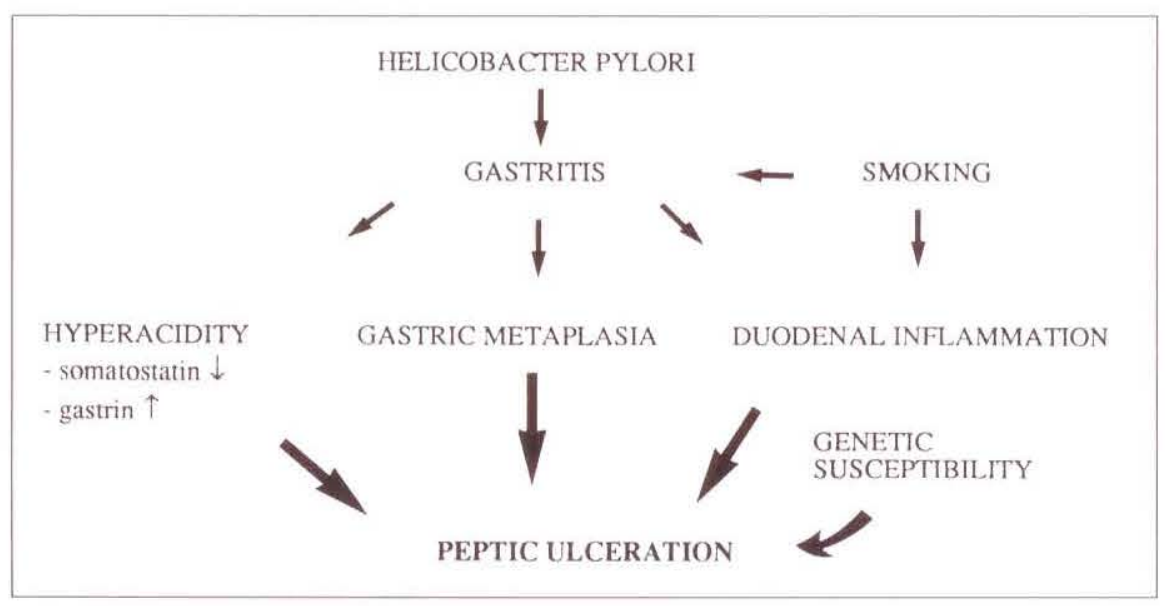

Figure 2) Mechanisms postulated for Helicobacter pylori-induced peptic ulceration

infection compared with controls (109). Age-matched controls are essential in these epidemiological studies as there is an age-dependent increase of asymptomatic $H$ pylori infection $(110$, 111). In addition, one study demonstrated that the clinical response following therapy eradicating $H$ pylori is not significantly better compared with the use of placebo (112).

$H$ pyloni seropositivity rates are not higher in children with functional recurrent abdominal pain compared with the prevalence of infection among agematched controls $(113,114)$. Our group was unable to identify a specific clinical symptom, or symptom complex, in the evaluation of children undergoing diagnostic upper endoscopy for symptoms of dyspepsia. In this study there were no factors that clearly segregated individuals with documented $H$ pylori infection from symptomatic patients without bacterial colonization of the antrum (115). In summary, there is little current evidence to suggest that in the absence of peptic ulceration $H$ pyloriinduced gastritis is a cause of clinical symptoms.

\section{H PYLORI-ASSOCIATED PEPTIC ULCER DISEASE}

Epidemiological studies identify a strong association between the presence of $H$ pylori infection in the antrum and duodenal ulcer disease (9). The epidemiological association of $\mathrm{H}$ pylori infection with gastric ulcer is less certain. The most convincing evidence demonstrating that $H$ pylori coloniza- tion of the antrum is causally related to peptic ulcer disease are studies which show that the relapse rate following healing of peptic ulcers is dramatically altered by eradicating $H$ pylori infection (116). The $80 \%$ one-year recurrence rate for peptic ulcers following standard ulcer-healing therapy is reduced to under $20 \%$ for both duodenal ulcers and gastric ulcers (117). These studies provide compelling evidence, therefore, that $H$ pylori infection is indeed related to gastroduodenal ulcer disease. In a recent excellent critical review of the potential role of $\mathrm{H}$ pylori in peptic ulceration, Moss and Calam (118) indicate that "all but the most perverse now accept the abundant evidence that $H$ pylori plays an important role in relapse of duodenal ulcer disease" and that "both marketing and scientific curiosity call for studies to determine how $H$ pylori does, or in most individuals does not, cause peptic ulcers".

It must be emphasized, however, that $H$ pylori infection does not fulfil each of Koch's postulates as a cause of peptic ulcer disease. Infected human volunteers develop chronic-active gastritis but not peptic ulceration $(5,6)$. Similarly, duodenal ulcers have not been described in the various animal models of helicobacter infection (7). Nevertheless, the accumulating and compelling evidence that eradication of $\mathrm{H}$ pylori infection results in a change in the natural history of recurrence of peptic ulceration raises questions regarding the etiopathogenesis of bacterial infection in the stomach and 


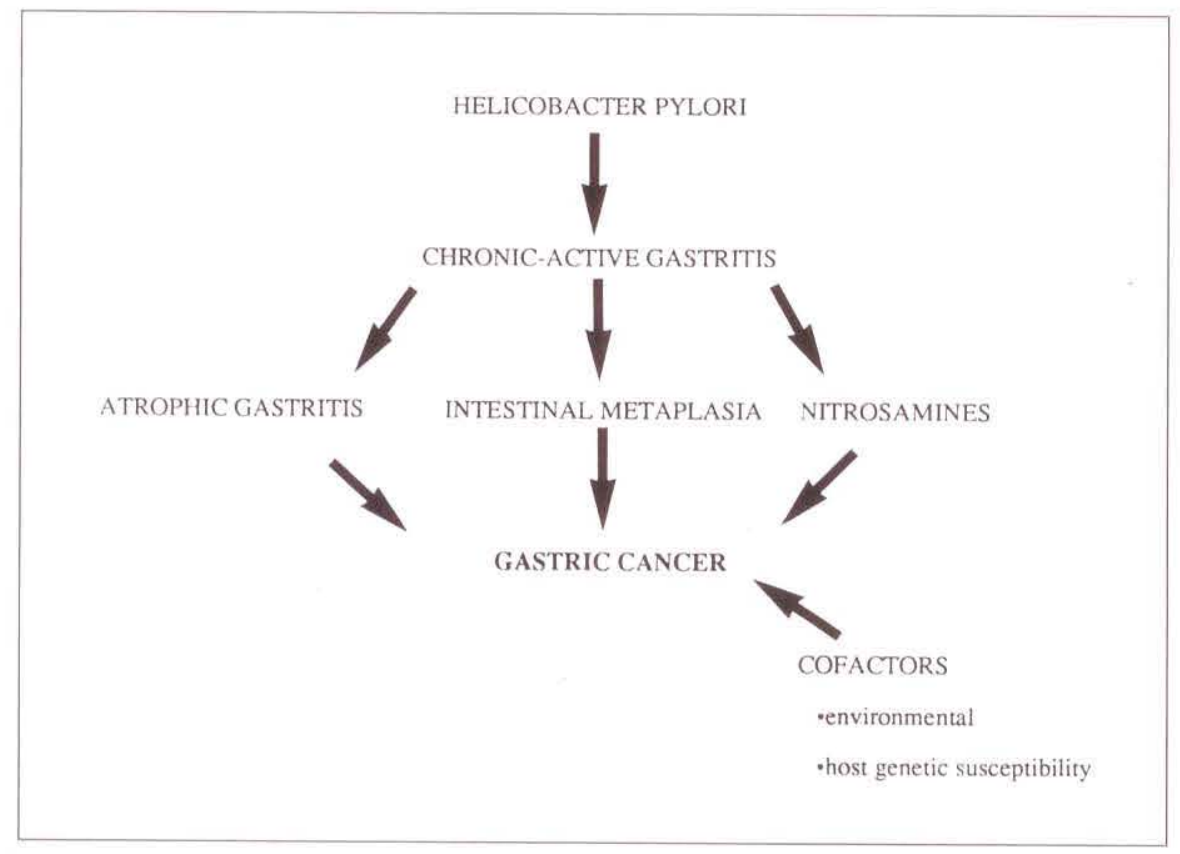

Figure 3) Possible pathways by which chronic Helicobacter pylori infection results in gastric cancers

associated peptic ulcer disease. Possible mechanisms for $H$ pylori-induced ulcerogenesis (Figure 2) are considered below.

Gastrin: Levy et al (119) reported that meal-stimulated gastrin levels are elevated in patients with $H$ pylori infection and duodenal ulcer disease. This exaggerated postprandial gastrin response, related primarily to gastrin-17 (120), is reduced towards normal following eradication of $H$ pylori infection (121). An exaggerated response following meals is also identified among patients with $H$ pylori infection in the absence of an ulcer diathesis (122). It has been suggested, therefore, that H pylori colonization of the antrum, and associated bacterial urease activity, results in a locally inappropriate elevation of luminal $\mathrm{pH}$ (123). Gastric $\mathrm{G}$ cells sense that there is too little acid in the gastric lumen and thereby produce increased amounts of gastrin in response to a meal. Increased gastrin could then result in postprandial excesses of acid and pepsinogen delivered into the first part of the duodenum and thereby induce peptic ulceration in the susceptible individual. This attractive hypothesis, however, has not been confirmed since other investigators have been unable to document a consistent increase in postprandial gastrin $(124,125)$ or specific mRNA (126) levels.

Somatostatin: Other investigators suggest that the postprandial excess in acid production following $H$ pylori infection may not be related to excessive amounts of gastrin, but rather due to decreased amounts of somatostatin $(127,128)$. Recent studies suggest that the amount of specific messenger RNA for somatostatin and somatostatin product translated by D cells in the stomach are both reduced in individuals with $\mathrm{H}$ pylori infection. Moreover, somatostatin transcription and translation products increase following eradication of $\mathrm{H} p \mathrm{py}$ lori infection (126). Since somatostatin release is involved in the control of acid production $(129,130)$, changes occurring with bacterial colonization of the antrum could result in excess delivery of acid into the duodenum and thereby promote ulcerogenesis in susceptible individuals.

Metaplasia: An alternate explanation for $H$ pylori-induced duodenal ulcer is that the organism colonizes inflamed mucosa in the duodenum. Wyatt et al (131) showed that metaplasia is more frequent among individuals with $H$ pylori infection and that duodenal ulcers frequently occur in the duodenum immediately adjacent to the foci of gastric metaplasia. We have reported similar findings in children with $H$ pylori infec. tion (132). The frequency of metaplasia in the first part of the duodenum was significantly higher in $\mathrm{H}$ pylori-infected children compared with age-matched subjects with gastritis due to causes other than H pylori infection or among patients without gastritis.

Duodenitis: Whether metaplasia in the duodenum is a risk factor for duodenal ulceration is not entirely clear because it is also associated with an active duodenitis (131-133). Duodenal inflammation is also more frequent among individuals with $H$ pylori infection of the antrum compared with individuals with secondary causes of gastritis or among subjects without evidence of gastritis (132). Longstanding mucosal inflammation may predispose the duodenum to active erosions and ulcerations in susceptible individuals. Release of the bacterial proinflammatory products listed in Table 2 into the duodenum could also induce proinflammatory responses in the proximal small bowel.

Cofactors: Additional risk factors such as smoking and reduced local cytoprotective effects, including reduced mucosal bicarbonate production in the first part of the duodenum (134), are also likely to be involved in determining which individuals will develop peptic ulceration. Genetic susceptibility and environmental risk factors, such as smoking, may ultimately determine which individuals among the large number of subjects with $H$ prlori infection ultimately will develop peptic ulcers. It should be emphasized, however, that smoking is a risk factor for ulceration only in the presence of $H$ pylori infection (135). The risk of recurrent ulceration with continued abuse of tobacco is evident only among subjects in whom the associated $H$ pylori infection is not successfully eradicated $(135,136)$.

In summary, with the evidence currently available it appears that $H$ pylori infection in the antrum is indeed related to peptic ulcer disease. Whether increases in postprandial gastrin, decreases in mucosal somatostatin production, gastric metaplasia in the duodenum, or chronic duodenal inflammation are primarily responsible for ulcerogenesis requires further evalu- 
ation. An animal model of helicobacter infection in which there is reproducible induction of duodenal ulcers would greatly facilitate this avenue of investigation.

\section{H PYLORI AND GASTRIC CARCINOMA}

Epidemiological studies have described an association between $H$ pylori infection and the development of a variety of types of gastric cancer (137139). Although epidemiological studies only identify an association and to not define cause and effect, they suggest that longstanding $H$ pylori infection, particularly if acquired during the childhood years (140), is an environmental risk factor for the development of gastric carcinoma. If confirmed, removing this risk factor could dramatically alter the significant morbidity and mortality associated with the development of gastric cancers (139).

The question of how longstanding $H$ pylori infection ultimately results in carcinogenesis is not well understood. As summarized in Figure 3, it has been proposed that longstanding inflammation in the stomach induces atrophy in the antrum and intestinal metaplasia in the body of the stomach; both events are reported to precede gastric cancer $(141,142)$. A recent study evaluating colonic carcinoma showed that nitrate production by neutrophils infiltrating into the local mucosal environment is a potential risk factor for carcinogenesis (143). Since neutrophilic infiltration is a histopathological feature of chronicactive gastritis in humans with $H$ pylori infection, it is of considerable interest to now determine whether neutrophils derived from gastric epithelium are also capable of forming procarcinogenic agents such as nitrates. In addition, the urease activity of $\mathrm{H}$ pylori may also be a factor in promoting gastric malignancy (144).

\section{CONCLUSIONS}

There has been a rapid explosion of information about the virulence properties of H pylori since the initial culture and identification of this organism by Marshall and Warren some 10 years ago. However, as shown in Table 3 , there remain a series of important unanswered questions. These include an understanding of the remarkable tissue tropism, the narrow host range and the marked genetic heterogeneity of $\mathrm{H} p$ lori $(145,146)$.

As summarized in Table 4, to better understand the virulence properties of H pylori it is important to now determine whether there are additional virulence factors expressed by the organism involved in the induction of chronicactive gastritis, duodenal ulceration and gastric carcinoma. The relative importance of the virulence factors identified to date, and summarized in this review, requires further evaluation. The dissection of the relative importance of $H$ pylori virulence determinants ultimately will be undertaken by improving our understanding of the genetic hasis and genetic control of the virulence properties of $H$ pylori. The identification, cloning and sequencing of additional genes within the $H$ pylori genome and a determination of those genes contributing to the virulence of the arganism are required. Successful identification and sequencing of urease genes in $H$ pylori and the creation of isogenic mutants indicate that the genetics of $H$ pylori infection will be a rapidly advancing field of investigation over the next several years.

Since normal immune and inflammatory responses are not sufficient to enable successful clearing of this infection once it has colonized the antrum, the host responses to bacterial infection also are a priority area of future investigation. An explanation of the lack of effective bacterial clearing could provide important insights into understanding the pathogenesis of this bacterial disease. In addition, novel therapeutic options may become evident. For example, the development of vaccines to prevent both recurrence of H pylori infection among successfully treated individuals and high risk uninfected populations should become possible with an improved understanding of the etiopathogenesis of disease. If bacterial adhesion is an essential virulence property, then defining the adhesin, or adhesins, could result in the development of effective passive and

\section{TABLE 3 \\ Pathogenesis of Helicobacter pylori infection: Unanswered questions}

Environmental reservoir(s)

Tissue tropism

Narrow host range

Strain variation

Relative importance of 'known'

virulence factors

\section{TABLE 4 \\ Virulence properties of Helicobacter pylori: Future directions}

Genetic understanding of virulence
Identification of virulence genes
Isogenic deletion of virulence genes
Host immune responses to infection
Host inflammatory response to infection
Animal models of infection with peptic
ulceration
Progression to malignancy
Vaccine development

active vaccine candidates. Such options are available for enteric infections in domesticated animals (147) and are in a rapid phase of development for enteric bacterial infections in humans (148).

Recent reports indicate that it will be possible to develop novel vaccines for preventing H pylori infection (149). Studies to date have employed an animal model to show that, in conjunction with small doses of cholera toxin given as adjuvant (150), an effective immune response develops which prevents bacterial colonization during subsequent oral challenge $(151,152)$. These initial findings hold out promise that safe and effective vaccines for use in the prevention of gastroduodenal diseases will become available in the future for therapeutic applications in humans.

ACKNOWLEDGEMENTS: P Sherman is the recipient of a Career Scientist Award from the Ontario Ministry of Health. B Gold is the recipient of a Fellowship Award from the Medical Research Council of Canada.

\section{REFERENCES}

1. Goodwin CS, Armstrong JA, Chilvers T. et al. Transfer of Campylobacter polori and Campolobacter mustelue to 
Helicolacter gen nov as. Helicobacter pylori comb nov and Helicobacter mustelae comb nov, respectively. Int ] Syst Bacteriol 1989;39:397-405.

2. Marshall BJ, Warren JR. Unidentified curved bacilli in the stomach of patients with gastritis and peptic ulceration. Lancet 1984;1:1311-5.

3. Drumm B, Sherman P, Cutz E, Karmali M. Association of Campylobacter pylori on the gastric mucosa with antral gastritis in children. N Engl ] Med 1987:316:1557-61.

4. Drumm B, O'Brien A, Cutz E, Sherman P. Campylobacter pyloridis-associated primary gastrit is in children. Pediatrics 1987;80:192-5.

5. Ormand JE, Talley NI, Shorter RG, et al. Prevalence of Helicobacter prtori in specific forms of gastritis. Dig Dis Sci 1991;36:142-5.

6. Marshall BJ, Armstrong JA, McGechie DM, Glancy RJ. Attempt to fulfill Koch's postulates for pyloric Campylobacter. Med J Aust $1985 ; 142: 436-9$.

7. Morris A, Nicholson G. Ingestion of Campylobacter pyloridis causes gastrit is and raised fasting gastric $\mathrm{pH} . \mathrm{Am}$ J Gastroenterol 1987;82:192-9.

8. Fox JG, Lee A. Gastric Campylobacter-like organisms: Their role in gastric diseases in laboratory animals. Lab Anim Sci 1989;39:1543-53.

9. Drumm B, Sherman P, Chiasson D, Karmali M, Cutz E. Treatment of Campylobacter pylori-associated antral gastrit is in children with hismuth subsalicylate and ampicillin. J Pediatr 1988:113:908-12.

10. Blaser MJ. Helicobacter pylori and the pathogenesis of gastroduodenal inflammation. I Infect Dis 1990 161:626-33.

11. Newell DG. Virulence factors of Helicobacter pylori. Scand I Gastroenterol 1991:26(Suppl 187):31-8.

12. Marshall B]. III. Virulence and pathogenicity of Helicobacter pylori. J Gastroenterol Hepatol 1991; 6:121-4.

13. Sinclair P. Virulence factors of Helicobacter pylori. Can J Gastroenterol 1991;5:214-8.

14. Finlay BB, Falkow S. Common themes in microbial pathogenicity. Microbicl Rev 1989;53:210-30

15. Taylor DN, Blaser MJ. The epidemiology of Helicobacter pylori infection. Epidemiol Rev $1991 ; 13: 42-59$.

16. Vaira D, D'Anastasia CD, Hulton J, et al. Campylobacter polori in abattoir workers: Is it a zoonosis? Lancet 1988;ii:725-6.

17. Perez-Perez GI, Marrie T, Inouve H, et al. The effect of age and occupation of the seroprevalence of Helicubacter pylori infection. Can J Infect Dis 1992:3:134-8.

18. Drumm B, Perez-Perez GI, Blaser MI. Sherman P. Intrafamilial clustering of Helicobacter pylori infection. N Engl ] Med 1990;322:359-63.

19. Thomas JE, Gibson JR, Darboe MK, Dale A, Weaver LT. Isolation of Helicobacter pylori from human faeces. Lancet 1992;340:1194-5.

20. Shames B, Krajden C, Fuksa M, Rabida C. Penner IL. Evidence for the occurrence of the same strain of Campvlobacter pylori in the stomach and dental plaque. J Clin Microbiol 1989;27:2849-50.

21. Mendall MA, Molineaux N, Toosy T. et al. Childhood living conditions and Helicobacter pylori seropositivity in adult life. Lancet 1992;339:896-7.

22. Mitchell HM, Li YY, Hu PJ, et al. Epidemiology of Helicobacter prlori in southern China: Identification of early childhood as the critical period for acquisition. J Infect Dis 1992;166:149-53.

23. Drumm B, Sherman P. Long-term storage of Campylobacter pylori. I Clin Microbiol 1989;27:1655-6.

24. Eaton KA, Morgan DA, Krakowka S. Motility as a factor in the colonization of gnotobiotic piglets by Helicobacter pylori. I Med Microbiol 1992;37:123-7.

25. Itoh $T$, Yanagawa $Y$, Shingaki $M$, et al. Isolation of Campylobacter pyloridis from human gastric mucosa and characterization of the isolates. Microbiol Immunol 1987;31:603-14.

26. Marshall BJ, Barrett LJ, Prakash C, MacCallum RW, Guerrant RL. Urea protects Helicobacter pylomi from the bactericidal effect of acid. Gastroenterology 1990;99:697-702.

27. Tzouvelekis LS, Mentis AF, Makris AM, Spiliadis C, Blackwell C, Weir DM. In vitro binding of Helicobacter pyloni to human gastric mucin. Infect Immun 1991;59:4252-4.

28. Sidebothom RL, Batten JJ, Karim QN, Spencer J, Baron JH. Breakdown of gastric mucus in the presence of Helicobacter pytori.] Clin Parhol 1991:44:52-7.

29. Sidebothom RL, Baron JH. Hypothesis: Helicobacter pylori urease, mucus, and gastric ulcer. Lancet 1990;335:193-5.

30. Howt in PR, Stacey AR, Newell DG. Investigation of the structure and localization of the urease of Helicobacter pylori using monoclonal antibodies. J Gen Microbiol 1990;136:1995-2000

31. Hills BA, Kirwood CA. Gastric mucosal harrier: Barrier to hydrogen ions imparted by gastric surfactant in vitro. Gut 1992;33:1039-41.
32. Kao Y.CJ, Lichtenberger LM. Phospholipid and neutral lipid-containing organelles of rat gastroduodenal mucous cells. Possible origin of the hydrophobic mucusal lining. Gastroenterology 1991;101:7-21.

33. Goddard PJ, Kao Y-CJ, Lichtenberger LM. Luminal surface hydrophobicity of canine gastric mucosa is dependent on a surface mucous gel. Gastroenterology 1990;98:361-70.

34. Spychal RT, Goggin PM, Marrero JM, et al. Surface hydrophohicity of gastric mucosa in peptic ulcer disease. Relationship to gastritis and Campylobacter pylori infection. Gastroenterology 1990;98:1250-4

35. Goggin PM, Marrere JM, Spychal RT, Jackson PA, Corbishley CM, Northfield TC. Surface hydrophobicity of gastric mucosa in Helicobacter pylori infection: Effect of clearance and eradication. Gastroenterology 1992;103:1486-90

36. Slomiany BL, Bilski J, Sarosiek J, et al. Campylobacter pyloridis degrades mucin and undermines gastric mucosal integrity. Biochem Biophys Res Commun 1987;144:307-14.

37. Baxter A, Campbell CJ, Cox DM, Grinham CJ, Pendlebury JE.

Proteolytic activities of human Campylobacter pylori and ferret gastric Campylobacter-like organism. Biochem Biophys Res Commun 1989;163:1-7.

38. Clayton CL, Pallen MJ, Kleanthous H, Wren BW, Tabaqchali S. Nucleotide sequence of two genes from Helicobacter pylori encoding for urease subunits. Nucl Acids Res 1990;18:368.

39. Hu L-T, Foxall PA, Russell R, Mobley HLT. Purification of recombinant Helicobacter pylori urease apoenzyme encoded by ure A and ure B. Infect Immun 1992;60:2657-66.

40. Cussac V, Ferraro RL, Labigne A. Expression of Helicobacter pylori urease genes in Escherichia coli grown under nitrogen-limiting conditions. I Bacteriol 1992;174:2466-73.

41. Ferraro RL, Cussac V, Courcaux P, Labigne A. Construction of isogenic urease-negative mutants of Helicobacter pylori by allelic exchange. J Bacteriol 1992;174:4212-7.

42. Tricottet V, Bruneval P, Vire (), et al. Campylobacter-like organisms and surface epithelium abnormalities in active, chronic gastritis in humans: $A_{n}$ ultrastructural study. Ultrastructural Pathol 1986;10:113-22.

43. Dytoc M, Gold B, Louie M, et al. Comparison of Helicobacter pylori and attaching-effacing Escherichia coli adhesion to eukaryotic cells. Infect Immun 1993:61:448-56.

44. Thomsen LL, Gavin JB, Tasman-Jones 
C. Relation of Helicobacter polori to the human gastric mucosa in chronic gastritis of the antrum. Gut 1990;31:1230-6.

45. Hessey SJ, Spencer J, Wyatt J1, et al. Bacterial adhesion and disease activity in Helicobacter associated chronic gastritis. Gut 1990;318:134-8.

46. Tesh VL, O'Brien AD. Adherence and colonization mechanisms of enteropathogenic and enterohemorrhagic Escherichia coli. Microbial Pathogen 1992;12:245-54.

47. Hemalatha S, Drumm B, Sherman P. Adherence of Helicobacter pylomi to human gastric epithelial cells in vitro. J Med Microbiol 1991;35:197-202.

48. Dunn BE, Altmann M. Campbell GP. Adherence of Helicohacter pylori to gastric carcinoma cells: Analysis by flow cytometry. Rev Infect Dis 1991;13(Suppl 8):S57-64.

49. Klein M, Drumm B. Adherence of Helicobacter pylowi to primary human gastrointestinal cells. Gastroenterology 1993;104:A56. (Abst)

50. Cave DR, Vargas M. Effect of Campylobacter pylori protein on acid secretion by parietal cells. Lancet $1989 ;$ ii: 187.9 .

51. Cave TR, Cave DR. Helicobacter pylori stimulates pepsin secretion from isolated rahbit gastric glands. Scand J Gastroenterol 1991;26(Suppl 181):9-14.

52. Young GO, Stemmet N, Lastovica A, et al. Helicobacter pylorit lipopolysaccharide stimulates gastric mucosal pepsinogen release. Aliment Pharmacol Ther 1992;6:169-77.

53. Veenendaal RA, Biemond I, Pena AS, Van Duijn W, Kreuning J, Lamers CBHW. Influence of age and Helicobacter pylori infection on serum pepsinogens in healthy blood transfusion donors. Gut 1992;33:452-5.

54. Yahav J, Oderda G, Diver-Haber A, Keller N, Jonas A. Mucosal peptic activity during Helicobacter pylori infection in pediatric patients. Gut 1992;33:1162-5

55. Kurata JH, Haik BM. Epidemiology of peptic ulcer disease. Clin Gastroenterol 1984;13:289-306.

56. Karlsson K-A, Angstrom J, Bergstrum J, Lanne B. Microbial interaction with animal cell surface carbohydrates. APMIS 1992;100(Suppl 27):71-83.

57. Lingwood C, Law H, Pellizzari A. Sherman P, Drumm B. A gastric glycerolipid as receptor for Campylobacter pylori. Lancet $1989 ; \mathrm{ii}: 238.41$

58. Lingwood CA, Huesca M. Kuksis A. The glycerolipid receptor for Helicobacter pylori (and exoenzyme S) is phosphatidylethanolamine. Infect Immun 1992;60:2470-4.
59. Gold B, Huesca M, Woods D, Sherman P, Lingwood C. Helicobacter mustelae binds to glycerolipid receptors in vitro. Gastroenterology 1992;102:A632. (Abst)

60. Saitoh T, Natomi H, Zhao W, et al. dentification of glycolipid receptors for Helicobacter pylori by

TLC-immunostaining. FEBS Lett 1991;282:385-7

61. Stomiany BL, Piotrowski J, Samanta A, Van Horn K, Murty VLW, Slomiany A. Campylobacter pylori colonization factor shows specificity for lactosylceramide sulfate and GM3 ganglioside. Biochem Int 1989;19:929-36.

62. Hasty DL, Ofek I, Courtney HS, Doyle RJ. Multiple adhesins of Streptococci. Infect Immun 1992;60:2147-52.

63. Emody L, Carlsson A, Ljungh A. Widstrom T. Mannose-resistant hemagglutination by Campylobacter promi. Scand 1 Infect Dis $1988: 20: 353-4$.

64. Huang J, Smyth CJ, Kennedy NP. Arbuthnott JP, Keeling PWN. Haemagglutinating activity of Campylobacter pylori. FEMS Microhiol Lett 1988;56:109-12.

65. Nakazawa T, Ishibashi M, Konishi H, Takemoto T, Shigeeda M, Kochiyame $T$. Hemagglutination activity of Campylobacter pylori. Infect lmmun 1989:57:989-91.

66. Evans [DG, Evans D], Moulds I], Graham DY. N-acetylneuraminyllactose-binding fibrillar hemagglutinin of Campylibacter pylori a putative colonization factor antigen. Infect Immun 1988;56:2896-906.

67. Evans DG, Evans DJ, Smith KE, Graham DY. Serum antibody responses to $\mathrm{N}$-acetylneuraminyllactose-binding hemagglutinin of Campylohacter pylori. Infect Immun 1989;57:664-7.

68. Armstrong JA, Cooper N, Goodwin $\mathrm{CS}$, et al. Influence of soluble hemagglutinins on adherence of Heticobacter pylori to HEp2 cells. J Med Microbiol 1991;34:181-7.

69. Lingwond CA, Cheng M, Krivan HC, Woods D. Glycolipid receptor binding specificity of exoenzyme $S$ from Pseudomonas aeruginosa. Biochem Biophys Res Commun 1991:175:1076-81

70. Doig P, Austin JW, Kostrzynska M, Trust TJ. Production of a conserved adhesin by the human gastroduodenal pathogen Helicobacter pylori. J Bacteriol 1992;174:2539-47.

71. Eaton KA, Brooks CL, Morgan DR, Krakowka S. Essential role of urease in pathogenesis of gastritis induced by Helicobacter pylori in gnotobiotic piglets. Infect Immun 1991;59:2470-5.

72. Newell DG, McBride H, Dolhy IM.
Investigations on the role of flagella in the colonization of infant mice with Camplobacter jeiuni and attachment of Campolobacter jejuni to human epithelial eell lines. I Hyg (Cambridge) 1985:95:217-27.

73. Drumm B, Neumann AW, Policova Z, Sherman P. Bacterial cell surface hydrophobicity properties in the mediation of in vitro adhesion by the rabbit enteric pathogen Escherichia colt stain RDEC - 1. I Clin Invest 1989;84:1588-94.

74. Pruul H, Goodwin CS, MCLonald PJ. Lewis G, Pankhurst D). Hydrophohic characterisation of Helicobacter (Camprlobacter) pvloni. I Med Microbiol 1990;32:93-100

75. Simith JI, Drumm B, Neumann AW, Policova Z, Sherman PM. In vitre surface properties of the newly recognized gastric pathogen Helicobacter pylori. Infect Immun 1990;58:3056-60.

76. Konishi H, Ishibashi M, Morshed MG. Nakazawa T. Cytopathic effects of Helicobacter pylori on cultured mammalian cells. J Med Microbiol 1992;37:118-22.

77. Xu J-K, Goodwin CS, Cooper M, Rohinson I. Intracellular vacuolization caused hy the urease of Helicobacter pyteri. J Infect Dis 1990;161:1302-4

78. Cover TL, Blaser MJ. Purification and characterization of the vacuolat ing toxin from Helicobacter pylom. I Biol Chem 1992;267:10570-5

79. Cover TL, Holter SA, Blaser MJ. Characterization of HeLa cell vacuoles induced by Helicohacter pylori broth culture supernatant. Hum Pathol 1992:23:1004-10.

80. Leunk RD, Ferguson MA, Morzan DR, Low DE, Simor AE. Antibody to cytotoxin in infection hy Helicobacter pylori. J Clin Microbiol 1990;28:1181-4.

81. Cover TL, Cao P, Murthy UK, Sipple MS, Blaser MJ. Serum neutralizing antibody response to the vacuolating cytotoxin of Helicobacter pylori. J Clin Invest 1992;90:913-8.

82. Figura N, Guglielmetti P, Rossolini A, et al. Cytotoxin production from Campylobacter pylori strains isolated from patients with peptic ulcers and from patients with gastritis only. J Clin Microbiol 1989;27:225-6.

83. Trust TJ, Doig P, Emody L, Kienle Z, Wadstrom T, O'Toole P. High-affinity binding of the basement membrane proteins collagen type IV and laminin to the gastric pathogen Helicobacter polori. Infect Immun 1991:59:4398-404.

84. Andersen LP, Holck S. Possible evidence of invasiveness of Helicobacter (Campylobacter) pylori. Eur J Clin Microbiol Infect Dis 1990;9:135-8. 
85. Evans DG, Evans D], Graham DY Adherence and internalization of Helicobacter pylowi by HEp-2 cells. Gastroenterology 1992:102:1557-67.

86. Kazi Jl, Sinniah R, Jeffrey NA, et al. Cellular and humoral immune responses in Campolobacter pylori-associated chronic gastritis. J Pathol 1989;159:231-7.

87. Rathbone BJ, Wyat JI, Worsley BW, et al. Systemic and local antibody responses to gastric Campylohacter pyloridis in non ulcer dyspepsia. Gut 1986:27:642-7.

88. Engstrand L, Scheynius A, Pahlson C, Grimelius L, Schwan A, Gustavsson S. Association of Campylobacter pylori with induced expression of class II transplantation antigens on gastric epithelial cells. Infect Immun 1989;57:827-32.

89. Mayer L, Eisenhardt D, Salomon P, Bauer W, Plous R, Piccinini L. Expression of class $I I$ molecules on intestinal epithelial cells in humans. Differences between normal and inflammatory bowel disease. Gastroenterology 1991;100:3-12.

90. Negrini R, Lisato L, Cavazzini L, et al. Monoclonal antilodies for specific immunoperoxidase detection of Campylobacter pylori. Gastroenterology 1989;96:414-20.

91. Negrini R, Lisato L, Zanelia 1, et al. Helicobacter pylori infection induces antibodies cross-reacting with human gastric mucosa. Gastroenterology 1991;101:437-45.

92. Mai UEH, Perez-Perez Gl, Wahl LM, Wahl SM, Blaser MJ, Smith PD. Soluble surface proteins from Helicobacter pylori activate monocytes/macrophages by a lipopolysaccharide, independent mechanism. J Clin Invest 1991:87:894-900.

93. Mai UEH, Perez-Perez GI, Allen JB, Wahl SM, Blaser MJ, Smith PD, Surface proteins from Helicobacter pylori exhibit chemotactic activity for human leukocytes and are present in gastric mucosa. J Exp Med 1992;175:517-25.

94. Dunn BE, Roop RM, Sung C-C, Sharma SA, Perez-Perez GI, Blaser MJ. Identification and purification of a cpn60 heat shock protein homolog from Helicobacter pylori. Infect Immun 1992;60:1946-51.

95. Evans DJ, Evans DG, Engstrand L, Graham DY. Urease-associated heat shock protein of Helicobacter pyloni. Infect Immun 1992;60:2125-7.

96. Denizot Y, Sobhani I, Rambaud J-C, Lewin M, Thomas Y, Beneviste J. Paf-acether synthesis by Helicobacter pyloni. Gut 1990;31:1242-5.

97. Langton SR, Cesareo SD. Helicobacter pylori associated phospholipase $A_{2}$ activity: A factor in peptic ulcer production? J Clin Pathol $1992 ; 45: 221-4$.

98. Czinn SI, Carr H, Young P. Demonstration of a soluble phosphodiesterase, phospholipase (PLC), produced by Helicobacter pylori: A potential virulence factor. Gastroenterology 1990;98:A 34. (Abst)

99. Hazell SL, Evans DJ, Graham DY. Helicohacter pylori catalase. I Gen Microbiol 1991;137:57-61.

100. Moran AP, Helander IM, Kosunen TU. Compositional analysis of Helicobacter pylori rough-form lipopolysaccharides. J Bacteriol 1992;174:1370-7.

101. Conrad RS, Kist M, Schlecht S, Golanos C. Extraction and hiochemical analysis of Helicobacter pylori lipopolysaccharide. Curr Microbiol 1992;24:165-9.

102. Muotiala A, Helander IM, Pyhala L, Kosunen TU, Moran AP. Low biological activity of Helicobacter pylori lipopolysaccharide. Infect Immun 1992;60:1714-6.

103. Mattsby-Baltzer I, Mieliniczuk Z, Larsson L, Lindgren K, Goodwin S. Lipid A in Helicobacter pylori. Infect Immun 1992;60:4383-7.

104. Crabtree JE, Shalleross TM, Heatley RV, Wyatt JI. Mucosal tumor necrosis factor a and interleukin-6 in patients with Helicobacter pylori associated gastritis. Gut 1991;32:1473-7.

105. Crabtree JE, Peichl P, Wyatt JI, Lindley IJD. Gastric interleukin-8 and anti-interleukin-8 IgA antibodies in Helicobacter pylori infection. Ir J Med Sci 1992;161(Suppl 10):20. (Abst)

106. Crowe S, Hunt RH, Jordana M, et al. Interleukin- 8 secretion by gastric epithelium following Helicobacter pylori infection in vitro. Gastroenterology 1993;104:A687A. (Abst)

107. Blaser MJ. Hypothesis on the pathogenesis and natural history of Helicobacter pylori induced inflammation. Gastroenterology 1992:102:720-7.

108. Elta GH. Helicobacter pylori in patients with nonulcer dyspepsia. Rev Infect Dis 1991;13(Suppl 8):S696-9.

109. Bemersen B, Johnsen R, Bostad L, Straume B, Sommer A-1, Burhol PG. Is Helicobacter pylori the cause of dyspepsia? Br Med J 1992;304:1276-9.

110. Gregson DB, Low DE, Cohen MM, et al. The prevalence of Campylobacter pylori gastritis among asymptomatic adults. Can Med Assoc J 1989;140:1449-53.

111. Dooley CP, Cohen H, Fitzgibbon FL, et al. Prevalence of Helicobacter pylori infection and histologic gastritis in asymptomatic persons. $N$ Engl ] Med 1989;321:1562-6.

112. Patchett S, Beattie S, Leen E, Keane C. O'Morain C. Eradicating Helicobacter pylori and symptoms of non-ulcer dyspepsia. Br Med J 1991;303:1238-40.

113. Fiedorek SC, Casteel HB, Pumphrey CL, et al. The role of Helicobacter pylori in recurrent, functional abdominal pain in children. Am J Gastroenterol 1992;87:347-9.

114. van der Meer SB, Forget PP, Loffeld RJLF, Stobbering LE, Kuijten RH, Arends JW. The prevalence of Helicubacter pylori serum antibodies in children with recurrent abdominal pain. Eur J Pediatr 1992;151:799-801.

115. Reifen R, Rasooly 1, Drumm B, Millson M, Murphy K, Sherman P. Symptomatology and demographic features of Helicobacter pylori infection in children. Ir J Med Sci 1992;161 (Suppl 10):25. (Abst)

116. Rauws EAJ, Tytgat GNJ. Cure of duodenal ulcer associated with eradication of Helicobacter pylori. Lancet 1990;335:1233-5.

117. Graham DY, Lew GM, Klein PD, et al. Effect of treatment of Helicobacter pylori infection on the long-term recurrence of gastric or duodenal ulcer. A randomized, controlled study. Ann Intern Med 1992;1 16:705-8.

118. Moss S, Calam J. Helicobacter pylori and peptic ulcers: The present position. Gut 1992;33:289-92.

119. Levi S, Beardshall K, Haddad G, Playford R, Ghosh P, Calam J. Campylobacter pylori and duodenal ulcers: The gastric link. Lancer 1989; ;:1167-8.

120. Beardshall K, Moss S, Gill J, et al. Suppression of Helicubacter pylori reduces gastrin releasing peptide stimulated gastrin release in duodenal ulcer patients. Gut 1992;33:601-3.

121. McColl KE, Fullerton GM, El-Nujumi AM, MacDonald AM, Brown IL, Hilditch TE. Lowered gastrin and gastric acidity after eradication of Campylobacter pyloni duodenal ulcer. Lancet 1989; ii:499-500.

122. Karnes WE, Ohning GV, Sytnik B, Kim SWR, Walsh JH. Elevation of meal-stimulated gastrin release in subjects with Helicobacter pylori infection: Reversal by low intragastric $\mathrm{pH}$. Rev Infect Dis 1991;13(Suppl 8):S665-70.

123. Graham DY, Opekun A, Lew GM, Klein PD, Walsh JH. Helicohacter pylori-associated exaggerated gastrin release in duodenal ulcer patients. The effect of bombesin infusion and urea ingestion. Gastroenterology 1991;100:1571-5.

124. Chittajallu RS, Dorrian CA, 
Neithercut WD, Dithill S, McColl KEL. Is Helicobacter pylori associated hypergastrinaemia due to the bacterium's urease activity or the antral gastritis? Gut 1991;32:1286-90.

125. Chittajallu RS, Neithercut WN, Ardill JES, McColl KEL. Helicobacter pylori-related hypergastrinaemia is not due to elevared antral surface pH. Studies with antral alkalinisation. Scand J Gastroenterol 1992;27:218-22.

126. Moss SF, Legon S, Bishop AE, Polak JM, Calam J. Effect of Helicobacter pyleri on gastric somatostatin in duodenal ulcer disease. Lancet 1992;340:930-2.

127. Kaneko H, Nakada K, Mitsuma T, et al. Helicobacter pylori infection induces a decrease in immunoreactive-somatostatin concentrations of human stomach. Dig Dis Sci 1992;37:409-16.

128. Murthy UK, Linscheer R, Cho C. The hypergastrinemia in Helicobacter pylori (HP)-gastritis is due to a decrease in antral D cell density and D:G cell ratio. Gastrocnterology 1992;102:A130. (Abst)

129. Schubert ML, Edwards NF, Makhlout GM. Regulation of gastric somatostatin secretion in the mouse by luminal acidity: A local teedback mechanism. Gastroenterology 1988;94:317-22.

130. Brand S], Stone D. Reciprocal regulation of antral gastrin and somatostatin gene expression by omeprazole-induced achlorhydria. J Clin lnvest 1988;82:1059-66.

131. Wyatt JI, Rathbone BJ, Sobala GM, et al. Gastric epithelium in the duodenum: Its association with Helicobacter pylori and inflammation. J Clin Pathol 1990;43:981-6.

132. Shabib S, Cutz E, Drumm B, Sherman P. Helicobacter pylomi infection is associated with gastric metaplasia in the duodenum in children. Gastroenterology 1992;102:A162. (Abst)
133. Gad A, Hradsky M, Furugard K. Malmodin B. Campylobacter pylori and gastroduodenal ulcer disease. A prospective study in a Swedish population. Scand J Gastroenterol 1989:24(Suppl 167):81-5.

134. Isenherg JI, Selling JA, Hogen DL, Koss MA. Impaired proximal duodenal bicarbonate secretion in patients with duodenal ulcer. N Engl J Med 1987;316:374-9

135. Borody TJ, George LL, Brandt S, Andrews P, Jankiewicz E, Ostapowicz N. Smoking does not contribute to duodenal ulcer relapse after Helicobacter pylori eradication. Am J Gastroenterol 1992;87:1390-3.

136. Chiverton SG, Hunt RH, Initial therapy and relapse of duodenal ulcer: Possible acid secretory mechanisms. Gastroenterology 1989;96:632-9.

137. Forman D, Newell DG, Fullerton F, et al. Association between infection with Helicobacter pylori and risk of gastric cancer: Evidence from prospective investigation. Br Med J 1991;302:1302-5.

138. Sipponen P, Kosumen TU, Valle J, Riihela M, Seppala K. Helicobacter pylori infection and chronic gastrit is in cancer. J Clin Pathol 1992;45:319-23.

139. Correa P. Is gastric carcinoma an infectious disease? N Engl J Med 1991;325:1170-1.

140. Parsonnet ], Friedman GD, Vandersteen DP, et al. Helicobacter pylori infection and the risk of gastric carcinoma. N Engl J Med 1991;325:1127-31.

141. Wee A, Kang IY, Teh M. Helicobacter pylori and gastric cancer: Correlation with gastritis, intestinal metaplasia, and tumor histology. Gut 1992:33:1029-32.

142. Craanen ME, Blok P, Dekker W, Fewerda J, Tytgat GN]. Subtypes of intestinal metaplasia and Helicobacter pylori. Gut 1992;33:597-600.
143. Grisham MB, Ware K, Gilleland HE. Gilletand LB, Ahell CL, Yamada T. Neutrophil-mediared nitrosamine formation: Role of nitric oxide in rats. Gastroenterology 1992;103:1260-6.

144. Tsujii M, Kawano S, Tsuji S, et al. Ammonia: A possible promotor in Helicobacter pylori-related gastric carcinogenesis. Cancer Letr $1992 ; 65: 15-8$

145. Simor A, Shames B, Drumm B, Sherman P, Low D, Penner J. Typing of Camprlobacter pylimi hy bacterial DNA restriction endonuclease analysis and determination of plasmid profile. J Clin Microbiol 1990;28:83-6.

146. Taylor DE. Genetics of Campylobacter and Helicobacter. Annual Rev Microbiol 1992:46:35-64.

147. Greenwood PE, Clark SJ, Cahill AD, Trevallyn-Jones J, Tsipori S. Development and protective efficacy of a recombinant-DNA derived fimbrial vaccine against enterotoxic collibacillosis in neonatal piglets. Vaccine 1988;6:389-92.

148. Tackett CO, Losonsky G, Link H, et al. Protection by milk inmunoglobulin concentrate against oral challenge with enterotoxigenic Escherichia coli. N Engl J Med 1988;318:1240-3.

149. Czinn SJ, Nedrud JG. Oral immunization against Helicobacter pyleri. Infect Inmun 1991;59:2359-63.

150. Elson CO. Cholera toxin as a mucusal adjuvant: Effects of $\mathrm{H}-2$ major histocompatibility complex and $4 p s$ genes. Infect Immun 1992;60:2874-9.

151. Chen M, Lee A, Hazell S. Immunisation against gastric helicobacter infection in a mouse/ Helicobacter felis model. Lancet 1992;339:1120-1.

152. Czinn S, Cai A, Nedrud J. Oral immunization protects germ-free mice against infection from Helicobacter felis. Gastroenterology 1992;102:A611. (Abst) 


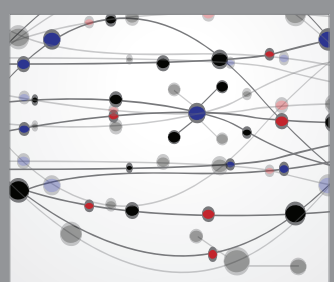

The Scientific World Journal


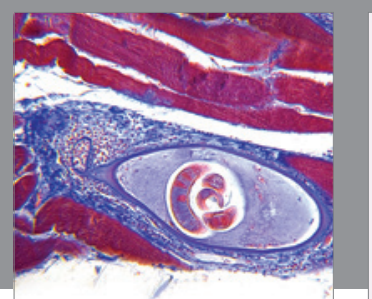

Gastroenterology Research and Practice

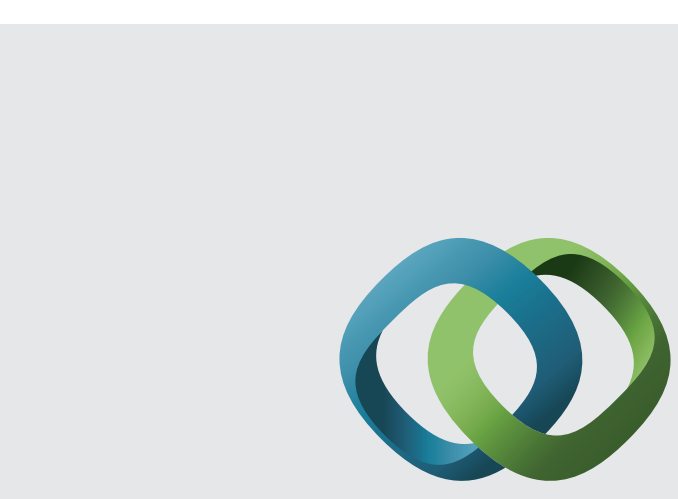

\section{Hindawi}

Submit your manuscripts at

http://www.hindawi.com
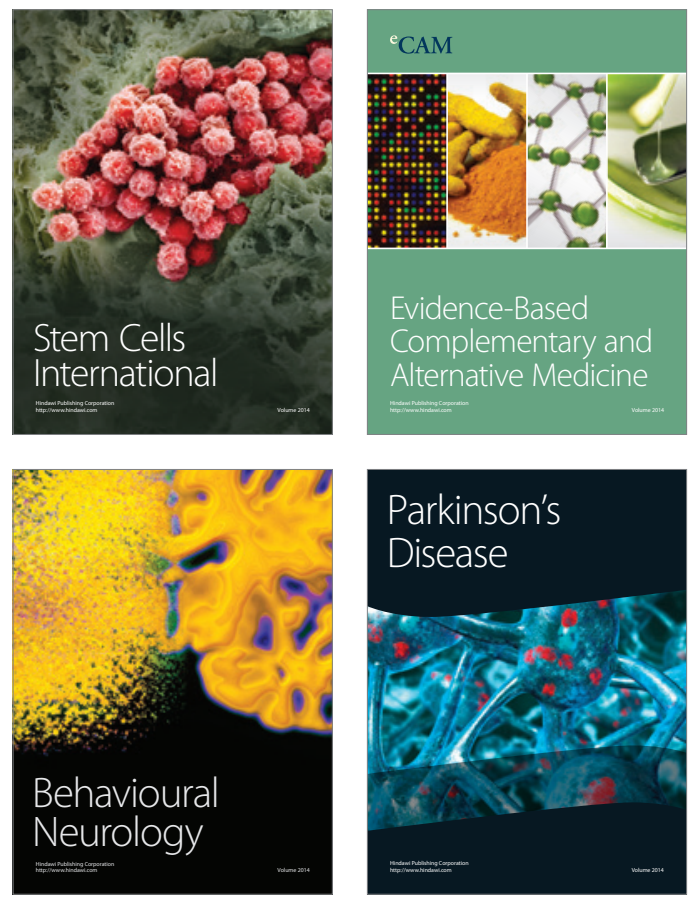
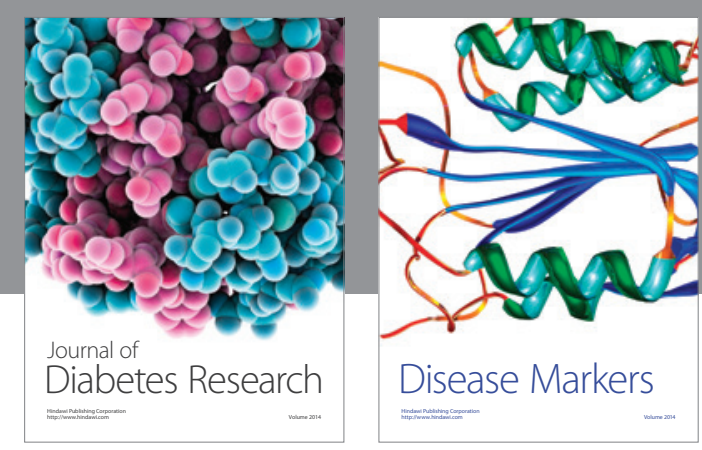

Disease Markers
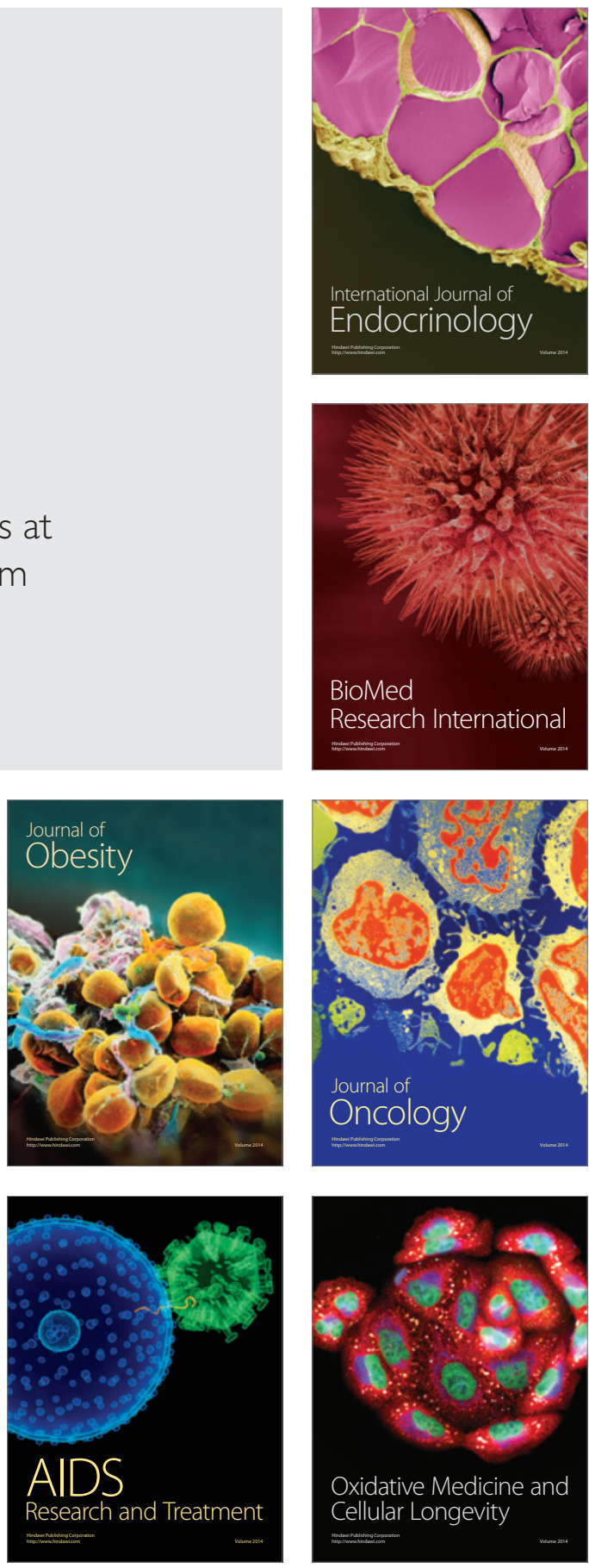